\title{
Bioaktivitas Formulasi Minyak Biji Azadirachta indica (A. Juss) terhadap Spodoptera litura F.
}

\author{
Raden Arif Malik Ramadhan ${ }^{1}$, Lindung Tri Puspasari ${ }^{1}$, Rika Meliansyah ${ }^{1}$, Rani Maharani ${ }^{2}$, \\ Yusup Hidayat ${ }^{1}$, dan Danar Dono ${ }^{1 *}$ \\ ${ }^{1}$ Departemen Hama dan Penyakit Tumbuhan, Fakultas Pertanian Universitas Padjadjaran \\ Jalan Raya Bandung-Sumedang KM 21. Jatinangor, Indonesia 45363. \\ ${ }^{2}$ Departemen Kimia, FMIPA Universitas Padjadjaran, \\ Jalan Raya Bandung-Sumedang KM 21. Jatinangor, Indonesia 45363. \\ *Penulis untuk korespondensi: danar.dono@unpad.ac.id
}

\begin{abstract}
Bioactivity Formulation of Seed Neem Oil Azadirachta indica (A.Juss) against Spodoptera litura (F)
\end{abstract}

The purpose of this research was to know the influence of neem seed extract formulation (Azadin $50 \mathrm{EC}$ ) on the mortality, larvae development, larvae weight, and food consumption of Armyworm (Spodoptera litura). This research used randomized complete design with 6 treatments and 5 replications, i.e. control, formula at concentration of $0.2 \%, 0.4 \% ; 0.8 \% ; 1.6 \%$; and $3.2 \%$. Correlation of concentration neem seed oil formulation and mortality of test insect was analysed using probit analysis, weight of test larvae presented in mean and standard deviation, and development time and food consumption of test larvae analysed with analysis of varians. Formula Azadin 50 EC had LC50 value of $0.659 \%(0.550-0.781 \%)$ at 12 days after treatment. The mortality increased significantly in pupae stage that caused $\mathrm{LC}_{50}$ value become $0.152 \%$. The formula prolonged development time, decrease the weight of test insect and decrease food consumption by the larvae.

Keywords: Lethal concentration, Mortality, Growth derangement, Extract

\begin{abstract}
ABSTRAK
Penelitian ini bertujuan untuk mempelajari perlakuan formulasi minyak biji mimba Azadin 50 EC terhadap mortalitas, perkembangan larva, bobot larva dan konsumsi pakan ulat grayak (Spodoptera litura F.). Metode Penelitian menggunakan Rancangan Acak Lengkap (RAL) dengan 6 perlakuan dengan 5 kali ulangan. Perlakuan tersebut yaitu : Kontrol, konsentrasi formula minyak mimba Azadin 50 EC 0,2\%; 0,4\%; 0,8\%; 1,6\% dan 3,2\%. Hubungan mortalitas dengan konsentrasi formula dianalisis menggunakan analisis probit, sedangkan data bobot larva, konsumsi pakan dan waktu perkembangan larva dianalisis dengan sidik ragam. Hasil penelitian menunjukkan bahwa formula minyak biji $A$. Indica memiliki nilai LC50 sebesar 0,659\% (0,550-0,781\%) terhadap larva instar 2 hingga instar 4. Pada fase pupa kematian kembali meningkat tajam sehingga nilai LC 50 menjadi $0,152 \%$. Perlakuan formula tersebut mengakibatkan perpanjangan waktu perkembangan, menurunkan bobot, dan menurunkan konsumsi pakan larva uji.
\end{abstract}

Kata Kunci: Konsentrasi letal, Mortalitas, Gangguan perkembangan, Ekstrak

\section{PENDAHULUAN}

Ulat grayak (Spodoptera litura F.) merupakan salah satu hama yang sangat merugikan bagi petani. Hama ini dilaporkan dapat menyerang lebih dari 200 spesies tanaman di antaranya cabai, kubis, padi, jagung, tomat, buncis, tembakau, terung, kentang, kacang tanah dan kacang kedelai. Hama $S$. litura dilaporkan tersebar di Jepang, Cina, India, serta di berbagai negara di Asia Tenggara (Marwoto \& Suharsono, 2008; Razak et al., 2014). 
Kehilangan hasil akibat serangan $S$. litura dapat mencapai $80 \%$, bahkan gagal panen apabila tidak dikendalikan (Marwoto \& Suharsono, 2008). Pengendalian terhadap serangga ini umumnya masih menggunakan insektisida kimia sintetik (Laoh dkk., 2003; Razak et al., 2014), sehingga peluang terbentuknya strain-starin baru yang lebih resisten semakin besar (Suharsono \& Muchlish, 2010).

Salah satu pengendalian alternatif yang dapat dilakukan di antaranya dengan menggunakan insektisida nabati. Beberapa keunggulan insektisida nabati antara lain memiliki tingkat persistensi yang rendah sehingga residunya mudah terurai di alam, relatif lebih aman dam dapat menekan berkembangnya resistensi hama, memiliki tingkat selektivitas tinggi sehingga aman bagi organisme non-target (Matsumura 1985; Untung, 2001).

Salah satu tanaman yang telah banyak diteliti sifat insektisidanya yaitu tanaman mimba (Azadirachta indica A. Juss.) (Meliaceae) dengan kandungan senyawa aktif utama azadirakhtin dan telah dilaporkan efektif terhadap lebih dari 400 spesies serangga yang tergolong ke dalam ordo Lepidoptera, Diptera, Orthoptera, Hemiptera, Coleoptera, Hymenoptera, Homoptera, Blattodea, Dermaptera, Siphonaptera, Isoptera, Thysanoptera, Pthiraptera dan Phasmida. Senyawa ini memiliki aktivitas insektisida, antifeedant, penghambat perkembangan dan penekan reproduksi serangga (Schmutterer \& Singh, 1995). Hampir seluruh bagian tanaman mimba dapat dimanfaatkan sebagai penghasil pestisida nabati, dan bagian yang memiliki daya toksisitas tinggi adalah bagian biji dan daun (Rukmana \& Yuyun, 2002). Namun, insektisida nabati yang ada dewasa ini jarang yang sudah dibuat dalam bentuk formulasi yang dapat menjamin ketersediaan penggunaannya bagi petani. Minyak biji mimba telah dibuat formulasinya dan diberi nama Azadin 50 EC merupakan formula baru insektisida nabati. Formula tersebut memiliki bahan aktif minyak biji mimba yang mengandung senyawa aktif utama azadirakhtin. Penelitian ini bertujuan mengetahui pengaruh pemberian formula insektisida ekstrak biji mimba terhadap $S$. litura.

\section{BAHAN DAN METODE}

Penelitian dilaksanakan di Laboratorium Pestisida dan Toksikologi Lingkungan, Departemen Hama dan Penyakit Tumbuhan, Fakultas Pertanian, Universitas Padjadjaran yanag berlangsung dari Februari hingga Juni 2015.
Metode percobaan yang digunakan merupakan metode eksperimental. Percobaan disusun dalam Rancangan Acak Lengkap (RAL). Penelitian ini terdiri atas 6 konsentrasi perlakuan formula minyak biji $A$. indica (Azadin $50 \mathrm{EC}$, yang diperoleh atas kebaikan Dr. Danar Dono). Perlakuan tersebut yaitu:

a. Kontrol

b. Formula minyak mimba Azadin 50 EC 0,2\%

c. Formula minyak mimba Azadin 50 EC 0,4\%

d. Formula minyak mimba Azadin 50 EC 0,8\%

e. Formula minyak mimba Azadin 50 EC 1,6\%

f. Formula minyak mimba Azadin 50 EC 3,2\%

Masing-masing perlakuan diulang sebanyak 3 kali pengulangan. Pengujian dilakukan dengan metode pencelupan daun pakan pada larutan formula sesuai konsentrasi perlakuan. Daun talas ungu berukuran $4 \times 4 \mathrm{~cm}$ dicelupkan pada larutan formula selama 5 detik sehingga seluruh daun pakan terbasahi secara merata. Selanjutnya daun dikeringanginkan dan setelah kering-angin daun dimasukkan ke dalam cawan petri beriameter $9 \mathrm{~cm}$ yang telah diberi alas kertas hisap. Kedalam setiap cawan petri dimasukkan 10 ekor larva $S$. litura instar I dengan menggunakan kwas halus. Pemberian pakan dengan perlakuan formula pada larva uji dilakukan selama 48 jam ( 2 x 24 jam), selanjutnya pakan diganti dengan pakan tanpa perlakuan hingga larva mencapai instar IV. Pengamatan dilakukan setiap hari. Parameter yang diamati dalam penelitian ini adalah kematian serangga uji, perkembangan serangga uji, bobot serangga pada instar IV, dan konsumsi pakan.

Data hubungan konsentrasi dengan kematian larva uji dianalisis menggunakan analisis probit (Finney 1971). Data waktu perkembangan dan bobot larva disajikan dalam bentuk nilai ratarata dan standar deviasi, sedangkan data konsumsi pakan dianalisis dengan analisis sidik ragam (Analysis of Variance). Perbedaan antar perlakuan pada konsumsi pakan diuji lanjut dengan menggunakan uji jarak berganda Duncan pada taraf $5 \%$.

\section{HASIL DAN PEMBAHASAN}

\section{Mortalitas Larva}

Kematian larva $S$. litura bergantung pada jumlah konsentrasi formula minyak mimba Azadin 50 EC yang diberikan. Berdasarkan hasil pengamatan, hubungan kematian dan konsentrasi formula minyak mimba Azadin 50 EC tertinggi 
terlihat pada 2 hari setelah perlakuan (HSP). Hal tersebut menunjukkan adanya interaksi antara larva $S$. litura dengan formula minyak mimba Azadin 50
EC yang bersifat mematikan seketika. Kematian mulai stabil pada 12 HSP hingga 20 HSP (Gambar 1).

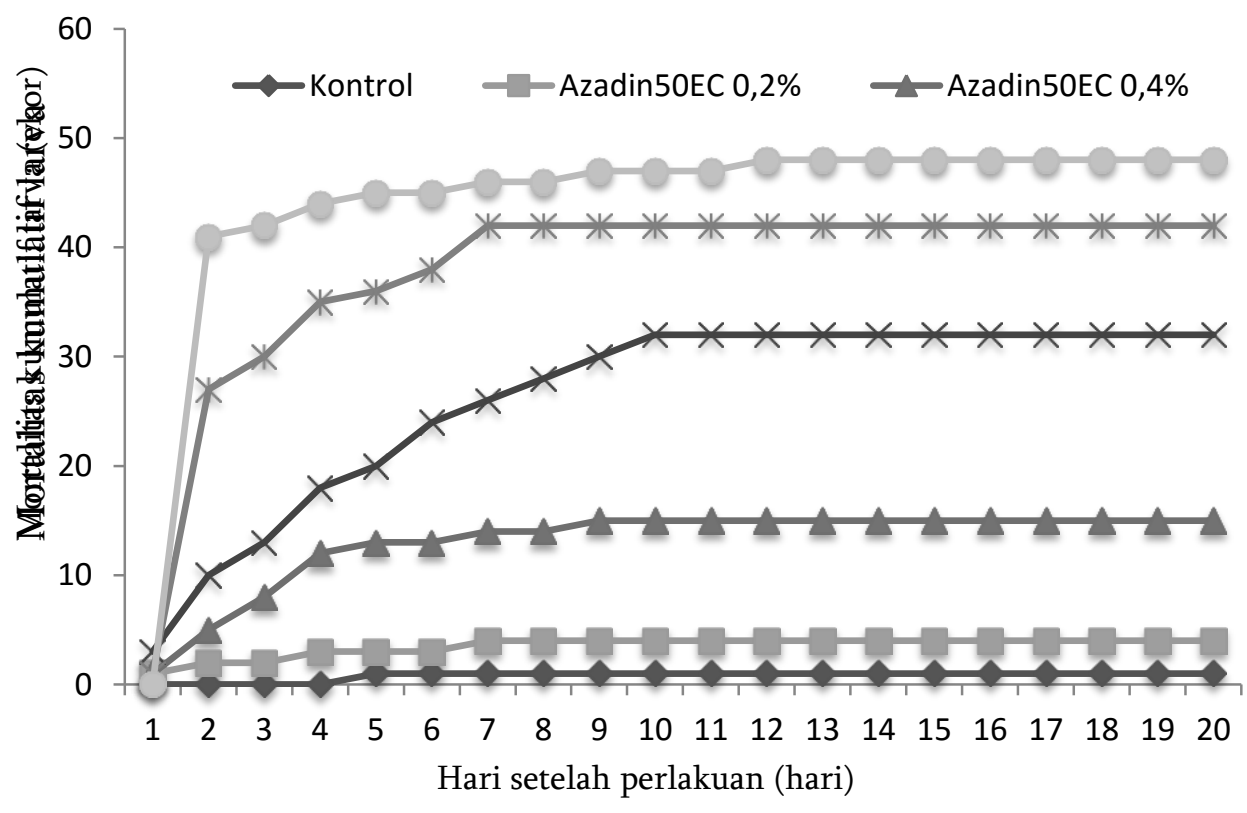

Gambar 1. Mortalitas kumulatif Spodoptera litura pada berbagai taraf konsentrasi formula minyak mimba Azadin 50 EC.

Hasil analisis probit dengan menggunakan program Polo Plus menunjukkan bahwa nilai LC menurun mulai dari 2 HSP hingga 12 HSP. Nilai LC yang semakin kecil mengindikasikan semakin toksiknya formula minyak mimba 50 EC yang diujikan. Nilai LC yang dihitung merupakan nilai LC50 dengan selang kepercayaan 95\% dengan pengamatan berdasarkan waktu (Tabel 1).

Tabel 1. Parameter regresi probit toksisitas formula minyak Azadirachta indica 50 EC terhadap $S$. litura berdasarkan waktu.

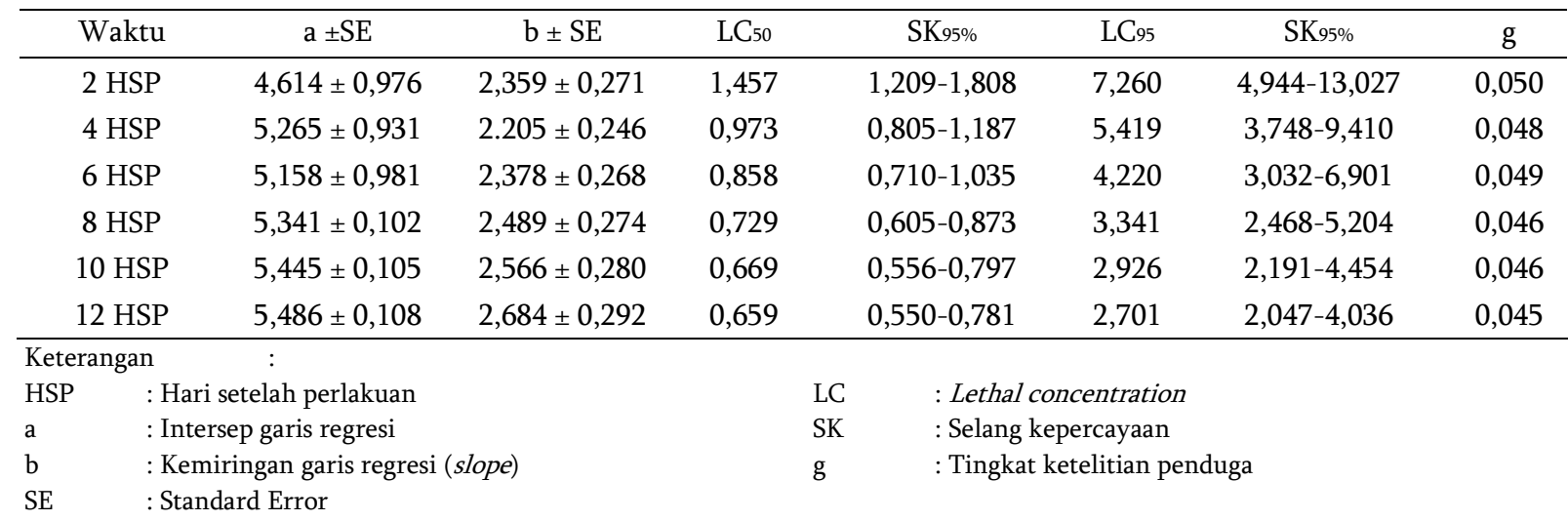

Penghitungan nilai LC50 kembali dihitung dengan pengamatan berdasarkan stadia $S$. litura dengan selang kepercayaan 95\%. Hasil analisis probit menunjukkan bahwa nilai LC menurun mulai dari stadia larva instar I hingga stadia imago (Tabel 2).

Perlakuan formula minyak mimba Azadin 50 EC mematikan pada stadia instar I hingga instar
II (1-4HSP), hal tersebut ditunjukkan oleh nilai LC 50 pada fase larva tersebut yaitu sebesar 0,742\%. Pada instar I hingga instar III nilai LC50 menurun sebesar 0,083\% dan pada kematian instar III hingga instar IV nilai LC50 cenderung stabil yang mengindikasikan tidak terjadi penambahan kematian serangga uji yang cukup berarti. Efek toksisitas jangka panjang formula minyak mimba 50 EC ditunjukkan pada 
stadia pupa dengan nilai $\mathrm{LC}_{50}$ menurun drastis sebesar $0.507 \%$. Hal tersebut mengindikasikan penambahan kematian $S$. litura yang signifikan terjadi pada tahap pupa. Hal tersebut menunjukkan bahwa formula berbahan aktif minyak biji $A$. Indica memiliki aktivitas penghambat perkembangan.

Tabel 2. Parameter regresi probit toksisitas formula minyak Azadirachta indica (Formula minyak mimba 50 EC) terhadap $S$. litura berdasarkan fase perkembangan serangga uji.

\begin{tabular}{lccccccc}
\hline \multicolumn{1}{c}{ Stadia } & $\mathrm{a} \pm \mathrm{SE}$ & $\mathrm{b} \pm \mathrm{SE}$ & $\mathrm{LC}$ & SK95\% $_{90}$ & $\mathrm{LC}_{95}$ & SK95\% & $\mathrm{g}$ \\
\hline Instar I-II & $5,357 \pm 0,106$ & $2,753 \pm 0,295$ & 0,742 & $0,623-0,877$ & 2,937 & $2,234-4,356$ & 0,044 \\
Instar I-III & $5,487 \pm 0,108$ & $2.684 \pm 0,292$ & 0,659 & $0,550-0,781$ & 2,701 & $2,047-4,036$ & 0,045 \\
Instar I-IV & $5,487 \pm 0,108$ & $2.684 \pm 0,292$ & 0,659 & $0,550-0,781$ & 2,701 & $2,047-4,036$ & 0,045 \\
Instar I-Pupa & $6,929 \pm 0,241$ & $2,359 \pm 0,453$ & 0,152 & $0.084-0.208$ & 0,758 & $0,562-1,314$ & 0,141 \\
Instar I-Imago & $7,761 \pm 0,521$ & $3,330 \pm 0,882$ & 0,148 & $0,071-0,197$ & 0,462 & $0,356-0,878$ & 0,269 \\
\hline
\end{tabular}

Senyawa azadirahtin dapat menyebabkan kematian seketika ataupun kematian secara bertahap terhadap serangga hama (Samsudin, 2011). Kematian akibat senyawa azadirachtin dapat terlihat signifikan pada hari kedua dan ketiga setelah aplikasi, kemudian pada hari kelima dan seterusnya kematian akan meningkat secara perlahan (Rafiq et al., 2012).
Pemberian senyawa azadirachtin terhadap hama $S$. litura memiliki pengaruh nyata terhadap hormon ecdysone yang terdapat pada hama $S$. litura tersebut. Gangguan pada hormon ecdysone tersebut mengakibatkan gangguan perkembangan larva dari suatu instar ke instar berikutnya termasuk pembentukan pupa (Jin-cheng et al., 2014).

Tabel 3. Pengaruh konsentrasi formula minyak mimba 50 EC terhadap perkembangan larva $S$. litura instar I hingga instar IV.

\begin{tabular}{|c|c|c|c|c|c|c|}
\hline \multirow{2}{*}{ Perlakuan } & \multicolumn{6}{|c|}{$\bar{x} \pm \mathrm{SD}$ (hari) } \\
\hline & Instar I-II & $\mathrm{n}$ & Instar I-III & $\mathrm{n}$ & Instar I-IV & $\mathrm{n}$ \\
\hline Kontrol & $3,780 \pm 0,422(a)$ & 49 & $7,220 \pm 0,743(a)$ & 49 & $11.370 \pm 1,395$ (a) & 49 \\
\hline Formula minyak mimba & & & & & & \\
\hline Azadin 50 EC 0,2\% & $4,350 \pm 0,635(\mathrm{ab})$ & 48 & $8,410 \pm 1,469(\mathrm{ab})$ & 46 & $12,330 \pm 1,136(\mathrm{ab})$ & 46 \\
\hline Formula minyak mimba & & & & & & \\
\hline $\begin{array}{l}\text { Azadin } 50 \text { EC } 0,4 \% \\
\text { Formula minyak mimba }\end{array}$ & $4,940 \pm 0,984(\mathrm{ab})$ & 36 & $9,170 \pm 0,891(b)$ & 35 & $13,060 \pm 0,906(\mathrm{ab})$ & 35 \\
\hline $\begin{array}{l}\text { Azadin } 50 \text { EC } 0,8 \% \\
\text { Formula minyak mimba }\end{array}$ & $5,730 \pm 1,386(b)$ & 22 & $8,830 \pm 1,098(\mathrm{ab})$ & 18 & $14,890 \pm 1,844(\mathrm{~b})$ & 18 \\
\hline $\begin{array}{l}\text { Azadin } 50 \text { EC } 1,6 \% \\
\text { Formula minyak mimba }\end{array}$ & $6,500 \pm 0,535(b)$ & 8 & $12,120 \pm 0,835$ (c) & 8 & $16.750 \pm 1.581(\mathrm{~b})$ & 8 \\
\hline Azadin 50 EC 3,2\% & $9,000 \pm 1,000(\mathrm{c})$ & 3 & $13,500 \pm 2,121(\mathrm{c})$ & 2 & $18,500 \pm 2,121(b)$ & 2 \\
\hline
\end{tabular}

Keterangan: Huruf yang sama pada satu kolom dalam tabel menunjukkan data tidak berbeda nyata dengan kontrol berdasarkan Uji Jarak Berganda Duncan 5\%.

SD : Standar deviasi

n : Jumlah populasi $S$. litura

\section{Perkembangan Larva}

Waktu perkembangan larva mengalami perpanjangan (terhambat) sesuai besaran konsentrasi formula minyak mimba Azadin 50 EC yang diberikan. Perkembangan larva pada perlakuan kontrol membutuhkan rata-rata waktu untuk mencapai instar IV selama 11,37 hari sementara pada konsentrasi tertinggi rata-rata waktu yang diperlukan untuk mencapai instar IV selama 18,5 hari (Tabel 3).
Hormon ecdysone merupakan hormon mengatur proses metamorfosis pada serangga, sehingga apabila hormon tersebut terganggu pembentukan pupa dan imago akan ikut terganggu (Ascher et al., 1983; Samsudin, 2011; Razak et al., 2014). Salah satu bentuk terganggunya hormon ecdyson ialah terhambatnya proses perubahan instar (Samsudin, 2011) dan bentuk fisik yang abnormal pada larva dan pupa $S$. litura (Jin-cheng et al., 2014). Selain gangguan pada hormon ecdysone, gangguan lain akibat pemberian insektisida nabati dapat 
berupa gangguan fisiologi serangga yang dapat dipengaruhi oleh aktivitas enzim protease dan invertase pada pencernaan serangga (Darwiati, 2009).

\section{Pembentukan Pupa dan Imago}

Pada stadia pra-pupa larva $S$. litura menunjukkan prilaku tidak aktif makan. Larva pada stadia pra-pupa akan mencari tempat persembunyian di balik tisu ataupun daun pakan apabila belum diberi media pasir untuk berpupa. Larva yang sudah siap berpupa akan segera menggali ke dalam pasir dan mengeluarkan cairan dari tubuhnya. Cairan tersebut kemudian mengeras dan berubah menyerupai benang-benang halus yang berguna untuk merekatkan butiran-butiran pasir di sekeliling tubuh larva. Dalam waktu 1-2 hari, larva normal dapat membentuk pupa sempurna dalam tanah. Pada perlakuan kontrol larva terbentuk sempurna dengan ukuran larva yang relatif lebih besar dari perlakuan lain. Pada perlakuan formula minyak mimba 50 EC 0,2\%, 0,4\%, 0,8\%, ditemukan banyak pupa maupun larva yang gagal berpupa kemudian mati.

Pada stadia pembentukan pupa ditemukan beberapa larva yang gagal membentuk pupa. Larva yang gagal membentuk pupa pada umumnya sudah menggali pasir, namun proses pembentukan pupa menjadi abnormal dan pada akhirnya mati di dalam tanah. Pada stadia pembentukan pupa menjadi imago, ditemukan beberapa pupa yang memiliki bentuk normal tetapi tidak berubah menjadi imago. Pupa yang tidak berubah menjadi imago tidak memperlihatkan tanda-tanda kehidupan sehingga pupa tersebut dinyatakan gagal membentuk imago. Keberhasilan pada proses perkembangan dari larva menjadi pupa dan dari pupa menjadi imago berhubungan dengan tingkat konsentrasi formula minyak mimba Azadin 50 EC yang diaplikasikan terhadap larva $S$. litura (Tabel 4).

Tabel 4. Hubungan pemberian konsentrasi formula minyak mimba Azadin 50 EC terhadap perkembangan larva menjadi pupa dan imago.

\begin{tabular}{|l|c|c|c|c|}
\hline \multirow{2}{*}{$\begin{array}{l}\text { Perlakuan } \\
\text { Kontrol }\end{array}$} & \multicolumn{2}{c|}{$\begin{array}{c}\text { Larva yang berhasil menjadi } \\
\text { pupa }\end{array}$} & \multicolumn{2}{c|}{$\begin{array}{c}\text { Pupa yang berhasil menjadi } \\
\text { imago }\end{array}$} \\
\cline { 2 - 5 } & $\mathrm{n}$ (Larva) & $\begin{array}{c}\text { Keberhasilan } \\
\text { berpupa (\%) }\end{array}$ & $\mathrm{n}$ (Pupa) & $\begin{array}{c}\text { Keberhasilan } \\
\text { berimago (\%) }\end{array}$ \\
\hline Formula minyak mimba 50 EC 0,2\% & 49 & $98 \%$ & 48 & $85 \%$ \\
\hline Formula minyak mimba 50 EC 0,4\% & 46 & $41 \%$ & 19 & $68 \%$ \\
\hline Formula minyak mimba 50 EC 0,8\% & 17 & $24 \%$ & 8 & $50 \%$ \\
\hline Formula minyak mimba 50 EC 1,6\% & 8 & $6 \%$ & 1 & $0 \%$ \\
\hline Formula minyak mimba 50 EC 3,2\% & 2 & $0 \%$ & 1 & $0 \%$ \\
\hline
\end{tabular}

Keterangan:

n : Jumlah populasi

Pada perlakuan kontrol pupa yang berhasil menjadi imago tampak normal tanpa adanya kelainan bentuk imago. Pada perlakuan 0,2\% terdapat dua ekor imago dengan kondisi sayap keriting sehingga imago tersebut kesulitan untuk terbang dan melakukan proses reproduksi. Pada perlakuan $0,4 \%$ hal serupa terjadi pada 3 imago, bahkan salah satunya memiliki toraks dan abdomen yang masih dalam bentuk pupa. Bagian kulit pupa yang mengeras tidak kunjung lepas dari bagian toraks dan abdomen imago hingga imago tersebut mati.

Kelainan pada bentuk pupa dan imago $S$. litura disebabkan akibat pengaruh senyawa azadirachtin (Razak et al., 2014). Senyawa azadirachtin memiliki struktur molekul kimia $\mathrm{C}_{35} \mathrm{H}_{44} \mathrm{O}_{16}$, struktur kimia azadirachtin tersebut menyerupai hormon ecdysone pada serangga dan dapat menganggu kerja hormon tersebut (Samsudin, 2011). Pembentukan fisik larva hingga pupa dapat dipengaruhi oleh senyawa azadirachtin yang mempengaruhi fungsi ecdysteroid receptor, pengkodean DNA serta RNA dari $S$. litura (Jin-cheng et al., 2014).

\section{Reproduksi Imago}

Pupa yang telah berhasil menjadi imago dipisahkan kedalam wadah plastik dan dipelihara hingga menghasilkan telur. Proses perkawinan berlangsung satu hingga dua hari kemudian imago 
betina meletakkan beberapa kelompok telur pada dinding wadah. Jumlah kelompok telur pada perlakuan kontrol berkisar antara 75-100 butir, pada perlakuan formula minyak mimba Azadin 50 EC 0,2\% tiap kelompok telur berjumlah 15-40 butir, sedangkan pada perlakuan $0,4 \%$ tidak ditemukan imago yang berhasil meletakkan telur.

Proses pembentukan telur dan peletakan telur $S$. litura dapat dipengaruhi oleh senyawa azadirachtin. Senyawa tersebut dilaporkan dapat menurunkan fekunditas (kemampuan bertelur) dan dapat menghambat proses peletakan telur pada imago S. litura (Ascher et al., 1983; Subiyakto, 2009).

\section{Bobot Larva}

Bobot larva pada perlakuan kontrol relatif lebih tinggi dibandingkan bobot larva yang terpapar formula minyak mimba Azadin 50 EC berbagai konsntrasi (Tabel 5). Hal tersebut ditunjang oleh data perkembangan larva yang terhambat akibat efek antifeedant sehingga larva cenderung tumbuh kerdil dan abnormal.

Tabel 5. Pengaruh konsentrasi formula minyak mimba Azadin 50 EC terhadap bobot larva $S$. litura.

\begin{tabular}{llc}
\hline \multicolumn{1}{c}{ Perlakuan } & $\mathrm{n}$ & $\bar{x} \pm \mathrm{SD}(\mathrm{g})$ \\
\hline Kontrol & 5 & $0,297 \pm 0,044$ \\
Formula minyak mimba Azadin 50 EC 0,2\% & 5 & $0,229 \pm 0,017$ \\
Formula minyak mimba Azadin 50 EC 0,4\% & 5 & $0,133 \pm 0,031$ \\
Formula minyak mimba Azadin 50 EC 0,8\% & 5 & $0,095 \pm 0,009$ \\
Formula minyak mimba Azadin 50 EC 1,6\% & 5 & $0,080 \pm 0,006$ \\
Formula minyak mimba Azadin 50 EC 3,2\% & 2 & $0,078 \pm 0,004$ \\
\hline
\end{tabular}

Keterangan:

$\mathrm{n} \quad$ : Jumlah ulangan yang digunakan untuk menimbang sampel larva

$x \quad$ : Rata-rata bobot larva (g)

SD : Standar deviasi (g)

Hasil pengamatan menunjukkan bobot beberapa larva III perlakuan kontrol lebih berat dibandingkan bobot larva instar IV pada perlakuan formula minyak mimba Azadin 50 EC 0,2\% dan $0,4 \%$. Secara visual dapat dilihat secara langsung bahwa larva yang terpapar formula minyak mimba Azadin 50 EC memiliki ukuran lebih kecil apabila dibandingkan dengan perlakuan kontrol.

Bobot dan ukuran larva sangat erat kaitannya dengan formula minyak mimba Azadin 50 EC yang bersifat antifeedant. Senyawa azadirachtin menimbulkan efek antifeedant sehingga terjadi penurunan konsumsi pakan larva $S$. litura. Penurunan konsumsi pakan tersebut mengakibatkan larva $S$. litura kekurangan nutrisi yang diperlukan untuk menunjang pertumbuhan larva, sehingga pertumbuhan larva menjadi terhambat dan bobot larva menjadi rendah.

Respon antifeedant sangat mempengaruhi bobot larva dan jumlah pakan yang dikonsumsi oleh larva $S$. litura. Rendahnya bobot larva diakibatkan oleh pengaruh senyawa azadirachtin terhadap respons penolakan prilaku makan (antifeedant) larva S. litura (Rafiq et al., 2012).

\section{Konsumsi Pakan}

Hasil pengamatan memperlihatkan bahwa perlakuan kontrol tidak berbeda nyata terhadap perlakuan formula minyak mimba Azadin 50 EC $0,2 \%$, namun berbeda nyata dengan perlakuan lain (Tabel 6). Penentuan notasi tiap perlakuan diuji lanjut menggunakan metode Duncan pada taraf kepercayaan 5\%.

Konsumsi pakan yang tinggi menandakan bahwa efek antifeedant tidak berbeda nyata pada perlakuan kontrol dan perlakuan formula minyak mimba Azadin 50 EC 0,2\%. Perlakuan kontrol berbeda nyata dengan perlakuan formula minyak mimba 50 EC $0,4 \%, 0,8 \%, 1,6 \%$ dan 3,2\%, hal tersebut ditandai dengan rendahnya konsumsi pakan yang terjadi pada saat pemberian pakan dengan daun berperlakuan.

Perilaku larva pada saat pengaplikasian formula minyak mimba Azadin 50 EC mengindikasikan efek antifeedant terhadap larva $S$. litura. Pada perlakuan kontrol dan perlakuan formula minyak mimba 50 Azadin EC 0,2\%, larva cenderung langsung bersembunyi dan mengkonsumsi pakan, pada perlakuan Formula minyak mimba 50 EC 0,4\% dan 0,8\% sebagian larva mengkonsumsi pakan dan sebagian larva menjauh dari pakan, sedangkan pada perlakuan formula minyak mimba Azadin 50 EC $1,6 \%$ dan 3,2\% seluruh larva bergerak menjauh dari pakan. 
Tabel 6. Pengaruh konsentrasi formula minyak mimba Azadin 50 EC terhadap jumlah konsumsi pakan larva S. litura.

\begin{tabular}{|c|c|c|c|}
\hline & Perlakuan & $\mathrm{n}$ & $\mathrm{x} \pm \mathrm{SE}(\mathrm{mg})$ \\
\hline & Kontrol & 10 & $10,6 \pm .2,4 \mathrm{c}$ \\
\hline Forr & minyak mimba Azadin 50 EC 0,2\% & 10 & $7,8 \pm 2,4 \mathrm{bc}$ \\
\hline Forr & minyak mimba Azadin 50 EC 0,4\% & 10 & $5,8 \pm 2,4 a b$ \\
\hline For & minyak mimba Azadin 50 EC 0,8\% & 10 & $5,4 \pm 2,4 \mathrm{ab}$ \\
\hline For & minyak mimba Azadin 50 EC 1,6\% & 10 & $2,8 \pm 2,6 \mathrm{a}$ \\
\hline Forr & minyak mimba Azadin 50 EC 3,2\% & 10 & $3,2 \pm 2,4 \mathrm{a}$ \\
\hline \multicolumn{4}{|c|}{ Keterangan: } \\
\hline $\mathrm{n}$ & \multicolumn{3}{|l|}{ : Jumlah daun perlakuan (lembar) } \\
\hline SK & \multicolumn{3}{|l|}{ : Selang kepercayaan } \\
\hline $\mathrm{x}$ & \multicolumn{3}{|l|}{ : Rata-rata konsumsi } \\
\hline $\mathrm{SE}$ & \multicolumn{3}{|l|}{ : Standard error } \\
\hline * & \multicolumn{3}{|c|}{ : Angka yang diikuti denganhuruf yang berbeda menunjukkan perbedaan yang signifikan menurut uji jarak berganda } \\
\hline
\end{tabular}

Antifeedant merupakan peristiwa gangguan perilaku berupa penghambatan kemauan serangga uji untuk mengkonsumsi pakan yang telah diberi perlakuan. Peristiwa tersebut disebabkan oleh susunan senyawa kimia dalam formula Formula minyak mimba Azadin 50 EC yang dapat mengacaukan sistem indera (efek antifeedant primer), atau mempengaruhi syaraf pusat serangga yang mempengaruhi proses makan (efek antifeedant sekunder) (Darwiyati, 2009).

\section{UCAPAN TERIMA KASIH}

Terima kasih disampaikan kepada Kementerian Riset, Teknologi dan Pendidikan Tinggi yang telah memfasilitasi penelitian Program Riset Andalan Perguruan Tinggi (RAPID) DP2M DIKTI tahun 2014/2015 dengan peneliti utama Dr. Danar Dono, Ir., M.Si.

\section{DAFTAR PUSTAKA}

Ascher, KRS, M Elyashu, EN Nadia, and J Meisner. 1983. Neem seed kernel extract as an inhibitor of growth and fecundity in Spodoptera littoralis. Departement of Toxicology, Agricultural Research Organization (ARO), The Volcani Center, Bet Dagan, Istrael. Proccedings of $2^{\text {nd }}$ International Neem Conference, Rauischholzhausen, Germany. Page 331344.

Darwiati, W. 2009. Uji efikasi ekstrak tanaman suren (Toona sinensis Merr.) sebagai insektisida nabati dalam pengendalian hama daun (Eurema spp. dan Spodoptera litura F.). [Tesis]. Fakultas Pertanian Institut Pertanian Bogor, Bogor.

Djojosumarto, P. 2008. Pestisida dan Aplikasinya. Agromedia Pustaka, Jakarta. 344 Halaman.

Finney DJ. 1971. Probit Analysis, $3^{\text {rd }}$ ed. Cambridge: Cambridge Univ Press. 336 pp.

Jin-cheng, Z, T Wu, L Liu, W Yang, and L He. 2014. EcR-RNAi and azadirachtin treatments induced the abnormal proleg development in Spodoptera litura. School of Life Sciences, East China Normal University, Shanghai 200241, China. Journal of East China Normal University vol. 1 page 133142.

Laoh, JH, F Puspita, dan Hendra. 2003. Kerentanan larva Spodoptera litura F. terhadap virus nuklear polyhedrosis. Jurusan Agronomi Fakultas Pertanian Universitas Riau, Pekan Baru, Riau. Jurnal Natur Indonesia 5 (2): 145-151.

Marwoto dan Suharsono. 2008. Strategi dan komponen teknologi pengendalian ulat grayak (Spodoptera litura Fabricius) pada tanaman kedelai. Balai Penelitian Tanaman Kacang-kacangan dan Umbi-umbian, Malang. Jurnal Litbang Pertanian 27 (4): 131-136.

Matsumura F. 1985. Toxicology of Insecticides, 2nd ed. New York: Plenum Press. 
Rafiq, M, MU Dahlot, SH Naqvi, M Mali, and N Ali. 2012. Efficacy of neem (Azadirachta indica A. Juss) callus and cells suspension extracts against three lepidopteron insects in cotton. Journal of Medicinal Plants Research 6 (40): 5344-5349.

Razak, TA, T Santhakumar, K Mageswari, and S Santhi. 2014. Studies on efficacy of certain neem products against Spodoptera litura (Fab.). J Biopest 7:160-163.

Rukmana, $\mathrm{R}$ dan $\mathrm{Y}$ Yuniarsih. 2002. Nimba Tanaman Penghasil Pestisida Alami. Kanisius, Yogyakarta. 39 Halaman.

Samsudin. 2011. Biosintesa dan cara kerja azadirachtin sebagai bahan aktif insektisida nabati. Balai Penelitian Tanaman Rempah dan Aneka Tanaman Industri. Hasil Prosiding Seminar Nasional Pestisida Nabati IV, Jakarta. Halaman 61-70.

Schmutterer, H. (ed.). 1995. The Neem Tree Azadirachta indica A. Juss. and Other
Meliaceous Plants: Sources of Unique Natural Products for Integrated Pest Management, Medicine, Industry and Other Purposes. VCH, Weinheim, Germany.

Subiyakto. 2009. Ekstrak biji mimba sebagai pestisida nabati: potensi, kendala, dan strategi pengembangannya. Balai Penelitian Tanaman Tembakau dan Serat, Malang. Perspektif 8 (2): $108-116$.

Suharsono dan M Muchlish A. 2010. Identifikasi sumber ketahanan aksesi plasma nutfah kedelai untuk ulat grayak Spodoptera litura F. Balai Penelitian Tanaman Kacangkacangan dan Umbi-umbian, Malang. Buletin Plasma Nutfah 16 (1): 29-37.

Untung, K. 2001. Pengantar Pengelolaan Hama Terpadu. Gadjah Mada University Press, Yogyakarta. 348 Halaman. 